\title{
КЕРАМІКА ВЛОДАВИ І ПАВЛОВА: ІСТОРІЯ, ТИПОЛОГІЯ, ХУДОЖНІ ОСОБЛИВОСТІ
}

\author{
Галина Івашків \\ Інститут народознавства НАН України \\ ORCID: 0000-0003-2359-6735
}

\begin{abstract}
Анотація. У статті висвітлено історію розвитку гончарства Влодави та Павлова до середини XX століття. Значні поклади глини, особливо багатої окисами заліза, давали змогу місцевим майстрам виготовляти передусім димлені вироби. У XVI ст. гончарний цех у Влодаві отримав великі привілеї, виробляючи різні види посуду. Мальована кераміка у Павлові з'явилася завдяки гончарям із Прикарпаття, зокрема з Кут (колишнє Станіславівське воєводство; зараз Івано-Франківська область). Визначено основні типологічні групи кераміки (посуд, предмети інтер'єру церков і помешкань - вази, скарбонки, а також іграшки), названо імена майстрів. Простежено художні особливості, зокрема основні техніки декору димлених (гладження, ритування) та мальованих (розпис кольоровими ангобами та поливою) глиняних виробів. Деякі з керамічних предметів застосовували в обрядах календарного й родинного циклів.
\end{abstract}

Ключові слова: гончарство, Влодава, Павлів, типи кераміки, декор

На кінець XIX - початок XX ст. припадає пік розвитку гончарства не лише в Україні, а й багатьох країнах Західної Свропи. У цей час на українських теренах було понад 700 гончарних осередків, які знаходилися в різних історико-етнографічних регіонах. Хоча в XX - на початку XXI ст. з'явилося чимало досліджень про діяльність таких центрів чи окремих народних майстрів, досі маловивченим $€$ гончарство місцевостей пограниччя, зокрема Лемківщини, Надсяння, Підляшшя та Холмщини. Так, незважаючи на те, що питання гончарного промислу порушувалося в колективній праці „Холмщина і Підляшшя” (1997), проте мистецтвознавча характеристика глиняних виробів не висвітлена.

Цікавою дослідницькою темою є гончарство Влодави і Павлова (Холмщина) до середини XX ст., включаючи характеристику типології виробів, їхнього оздоблення та застосування в обрядах і звичаях календарного й родинного циклів. Розвиткові цих гончарних осередків сприяли значні поклади глини, особливо багатої окисами заліза, звідси й перевага у виготовленні димлених виробів. 
Про окремі сторінки керамічного промислу у Влодаві й Павлові йшлося у працях польських та українських дослідників, зокрема Оскара Кольберга ${ }^{1}$, Станіслава-Едмунда Михальського ${ }^{2}$, Романа Райнфуса ${ }^{3}$, Юрія Лащука ${ }^{4}$, Тетяни Кари-Васильєвої ${ }^{5}$, Галини Івашків ${ }^{6}$ та інших.

Вироби з цих осередків зберігаються в музеях України та Польщі, зокрема Музеї етнографії та художнього промислу Інституту народознавства НАН України (далі - МЕХП), Державному Етнографічному музеї у Варшаві (далі - ДЕМВ), Музеї Люблінщини у Любліні (далі - МЛЛ), Національному музеї у Кракові (далі - НМК), Етнографічному музеї у Кракові (далі - ЕМК), Музеї Ленчинсько-Влодавського поозер'я (далі - МЛВП), Музеї гімназії у Волі Угруській Влодавського повіту Люблінського воєводства (далі - МГВУ), Музеї-садибі в с. Голі (далі - МСвГ), приватних збірках. Різними були шляхи надходження предметів до музеїв. Так, 1938 р. до Музею Наукового товариства імені Т. Шевченка (далі - НТШ) групу керамічних предметів з Влодави та Павлова подарував Зенон Калужняцький ${ }^{7}$.

Влодава (в давніх документах - Володава) - центр повіту Люблінського воєводства, розташована на річці Західний Буг, зокрема в його західній частині, де протікає річка Влодавка. У 1599 р. місцевий гончарний цех отримав великі привілеї, виробляючи різні види посуду - місто здавна славилося димленою керамікою. У XVIII ст. майже половину населення Влодави складали євреї, які зазвичай займалися торгівлею, орендою і ремеслами, пов'язаними зі своїми традиціями (пекарі, м'ясники, шевці, кушніри, капелюшники, золотарі). Християни були переважно землеробами, столярами, мулярами та гончарями 8 . У 1914 р. тут працювало 30, 1939 - 12 гончарів. В одному зі списків зареєстрованих влодавських ремісників значаться 15 і 2 гончарі-християни за 1928 та 1937 рр. відповідно9, а за даними іншої таблиці підтверджено 100-від-

O. Kolberg, Chetmskie (obraz etnograficzny), Kraków 1890, t. 1, s. 83-85.

S. E. Michalski, Włodawa. Monografia statystyczno-gospodarcza, Lublin 1939, 138 s.

R. Reinfuss, Garncarstwo ludowe, Warszawa 1955, s. 17, tab. 9; idem, Na marginesie badań sztuki ludowej Białostocczyzny, „Polska Sztuka Ludowa” 1961, № 3, s. 131-136; idem, Sztuka ludowa na pograniczu Lubelszczyzny i Podlasia, [w:] Studia i Materiały Lubelskie. Etnografia, Lublin 1962, s. 136-138.

4 Ю. Лащук, Народне мистеитво Украӥнського Полісся, Львів 1992, с. 79.

5 Т. Кара-Васильєва, Ремесла і народне мистецтво. Гончарство, [в:] Холмщина і Підляшшя. Історико-етнографічне дослідження, Київ 1997, с. 223-231.

6 Г. Івашків, Декор украӥнської народної кераміки XVI- першої половини XX століть, Львів 2007, с. 182.

7 Інвентарна книга музею НТШ № VII (зберігається в МЕХП).

8 Włodawa - The Card of Cultural Heritage, [źródło internetowe:] https://www.eu/uk/ włodawa-the-card-of-nationał-heritage, dostęp: 29.05.2020.

$9 \quad$ S. E. Michalski, op. cit., s. 51. 
соткове заняття гончарством саме серед християн ${ }^{10}$. До операції „Вісла” у Влодаві мешкало багато українців. 3 їхнім виселенням після Другої світової війни гончарний центр припинив своє активне функціонування. Відомо декілька прізвищ майстрів, серед яких С. Наливайко, Я. Курась, О. Вальчук, В. Курчук ${ }^{11}$.

На початку 1870 -х рр. у Влодаві працювало три ${ }^{12}$, а в 1878 р. дев'ять цегелень ${ }^{13}$. У 1920-х рр. у Влодавському повіті зафіксовано вже 37 таких підприємств, 3 них два - недалеко від Влодави ${ }^{14}$. Про занепад цегельного виробництва свідчить те, що в 1933 р. з Катовіц і Холма до Влодави було привезено 2868 цегол ${ }^{15}$. Ще в 1990 -х рр. у повіті працювало декілька цегелень: в Угруську (власник Квятковський) та в околиці Волі Угруської (власник Бернацький $)^{16}$.

Певний час у Влодаві свою продукцію (кахлі та інші предмети побуту) випускала „стара кафлярня”, приміщення якої і зараз знаходиться за мостом, з іншого боку річки Влодавки, де колись був млин Теофіля Залевського і Шуліма Лемберга (Іл. 1).

Одним із найбільших гончарних осередків Холмщини дослідники вважають Павлів, історія якого сягає 1646 року. У 1779 р. тут працювало 28 , а в 1860 р. -86 гончарів ${ }^{17}$. Про розвиток гончарного промислу на основі покладів доброї глини у 1886 р. йшлося на сторінках „Словника географічного Королівства польського і інших країв слов'янських”"

Серед прізвищ майстрів: Беган, Клин, Козел, Кош, Копець, Пастульжинський, Козицький, Дерезинка, Бекань, Шовкалюк, Дудек, Савицький, Кардашинський ${ }^{19}$, а також Катерина Цехомська, Микола і Томаш Філіпчуки, Михайло Клин, Мечислав Кейда, Станіслав Копсевич, Францішек і Мечислав Концевичі, Іван Козел, Олександр Козловський, Іван і Владислав Квятковські, Станіслав Накельський, Антон та Іван Славінські, Антон і Казимир Канарські, Казимир Жолнач ${ }^{20}$ та інші.

\footnotetext{
$10 \quad$ Ibidem, s. 57.

11 Т. Кара-Васильєва, ор. cit., с. 227.

12 Stownik geograficzny Królestwa Polskiego i innych krajów słowiańskich, Warszawa 1893 , t. 13 , s. 712 .

13 Ibidem, s. 713.

14 S. E. Michalski, op. cit., s. 6, 44.

15 Ibidem, s. 92.

16 Записано 8.06.2019 р. у Волі Угруській Влодавського повіту від заступника директора місцевої гімназії Іоланти Шахалай.

17 Т. Кара-Васильєва, ор. cit., с. 229.

18 Stownik geograficzny Królestwa Polskiego i innych krajów słowiańskich, Warszawa 1886, t. 7, s. 905 .

19 Т. Кара-Васильєва, ор. cit.

20 Інвентарні книги МЛЛ.
} 


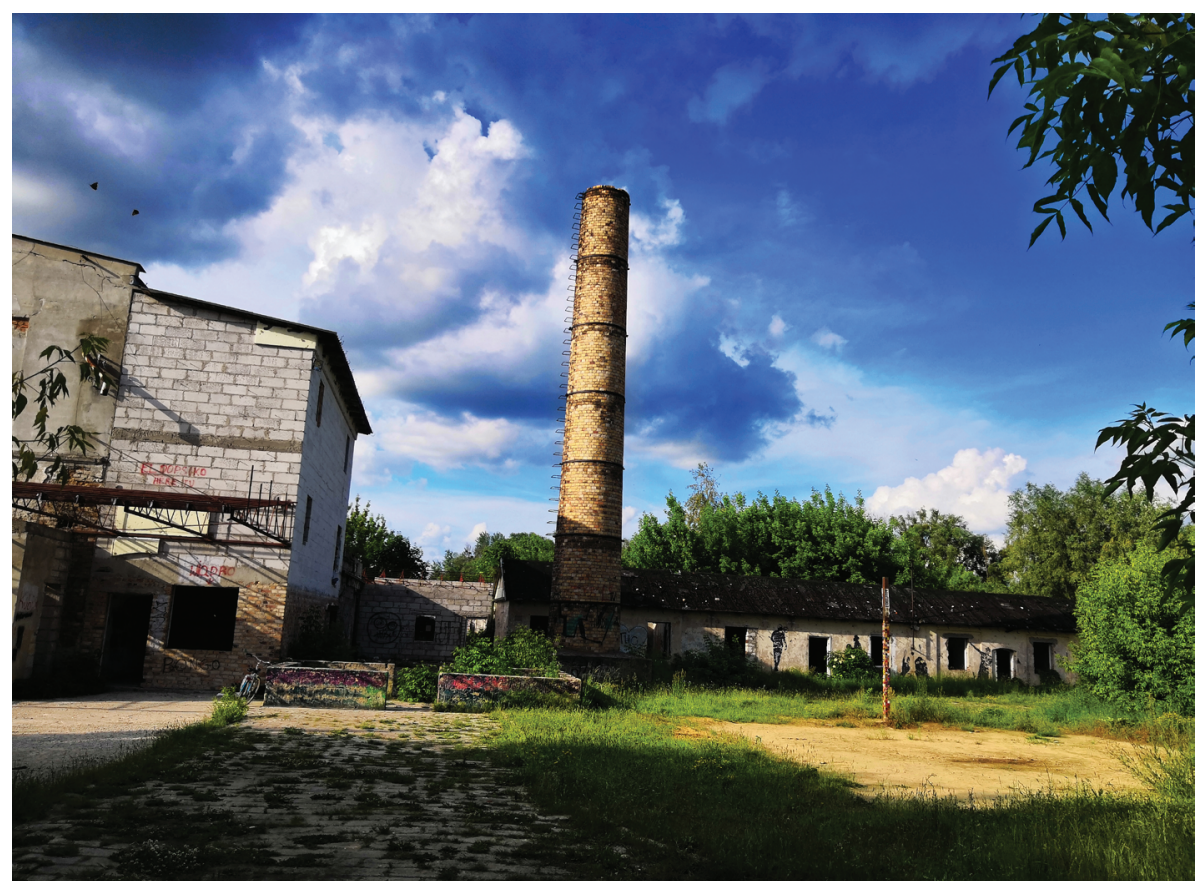

Іл. 1. Стара „кафлярня”. Влодава. Фото Галини Івашків.

Бувало, що майстри керамічної справи переїжджали 3 одного села в інше і влаштовували там свої робітні. 3 кінця ХІХ ст. до 1948 р. функціонував центр гончарства в Росоші, який і заснували гончарі з Павлова та Влодави ${ }^{21}$. Там зокрема працював Йосип Козел ${ }^{22}$.

Через конкуренцію майстрів та значне поширення мальованої кераміки попит на димлені вироби („сиваки”, пол. „siwaki”) щоразу зменшувався, тому гончарі намагалися переорієнтувати свою діяльність відповідно до нових вимог. Важливу роль у цьому відіграли гончарі-українці 3 Галичини (за Р. Райнфусом, „гончарі з Галіції”) ${ }^{23}$, які, згідно з зафіксованою в Павлові інформацією, вже близько 1890 р. навчали гончарів 3 Павлова малювати і вкривати поливою посуд та інші вироби ${ }^{24}$.

Перед Другою світовою війною у Павлові торгували брати Петро, Кузьма й Микола Чепіги та Микола Буц із Кут (колишнє Станіславівське воєводство; зараз Івано-Франківська область), до яких і звернулися місцеві майстри за порадою. Згодом до Павлова запросили знаного кут-

\footnotetext{
21 Т. Кара-Васильєва, ор. cit. с. 227.

22 Вироби майстра $є$ у фондах МЛЛ.

23 R. Reinfuss, Sztuka ludowa... op. cit., s. 137.

24 Ibidem.
} 
ського гончаря Михайла Волощука (1906-1959), який навчав усіх охочих мистецтва мальованої кераміки ${ }^{25}$.

У період окупації Польщі німецькими військами до Павлова з Покуття прибули гончарі Антон Славінський (1888-1965) та його син Іван (1921-?), які володіли техніками ритування і мотивами т. зв. „гуцульського” чи „покутського” стилю із застосуванням тріади кольорів - брунатного, жовтого і зеленого на білому тлі ${ }^{26}$. Через деякий час мальовану кераміку Павлова вже пов'язували з іменами Томаша (1913-1980) й Миколи (1881-1958) Філіпчуків, які оздоблювали свої вироби здебільшого рослинними мотивами (МЛЛ).

Як відомо, керамічні вироби укладають у роди, типологічні групи і підгрупи закритого і відкритого типів. Відтак, однією з найбільших типологічних груп $\epsilon$ посуд, зокрема для повсякденного використання та обрядового призначення. Якщо у Влодаві виготовляли винятково димлену кераміку, то в Павлові, як уже йшлося, й мальовану. Одні майстри спеціалізувалися на димлених виробах, інші - мальованих (Антон Славінський, Катерина Цехомська, Томаш і Микола Філіпчуки), а деякі це поєднували. Так, є чимало зразків димленого посуду, а також кераміки іншого виду, оздобленої кольоровими ангобами, роботи Івана Славінського (МЛЛ). Коли йдеться про вироби з білим тлом, то в розписі таких предметів застосовано традиційні для кераміки Гуцульщини та Покуття кольори. Для прикрашення виробів із цеглястим тлом використано здебільшого лише білий ангоб, який після покриття безколірною поливою давав жовтавий відтінок.

Із димленого посуду з побутовою функцією можна виокремити кілька типів, серед яких горщики: менші - для приготування їжі (за О. Кольбергом, горщик-варишок; пол. waryszok $^{27}$ ), більші - для зберігання муки та круп. Вони були переважно з вивернутими назовні вінцями, короткою шийкою, кулястим корпусом та невеликим дном. Горщик міг бути декорований ритованими лініями на вінцях та плічках, а далі по всій поверхні вертикальними гладженими (лискованими) зигзагами (Влодава, МЕХП). Інколи оздобою були дві ритовані лінії під вінцями (Влодава, МЛВП). Деякі горщики з циліндричним корпусом та одним вухом або без них декоровано мотивами потрійних гладжених скісних хрестів, які чергуються 3 мотивами овалів або „сосонок”, укладених горизонтально, чи короткими лініями і „сосонками” (І. Славінський, Павлів, МЛЛ).

Мальовані горщики 3 цеглястим тлом оздоблено мотивами ліній i кривульок, скісних хрестів і гілок (І. Славінський, МЛЛ), групами

\footnotetext{
25 Т. Кара-Васильєва, ор. сіt., с. 229.

26 Записано 27.11.2002 р. в Музеї Люблінщини у Любліні від Агнєшки Лавіцької, завідуючої відділом етнографії.

27 O. Kolberg, op. cit., s. 83.
} 


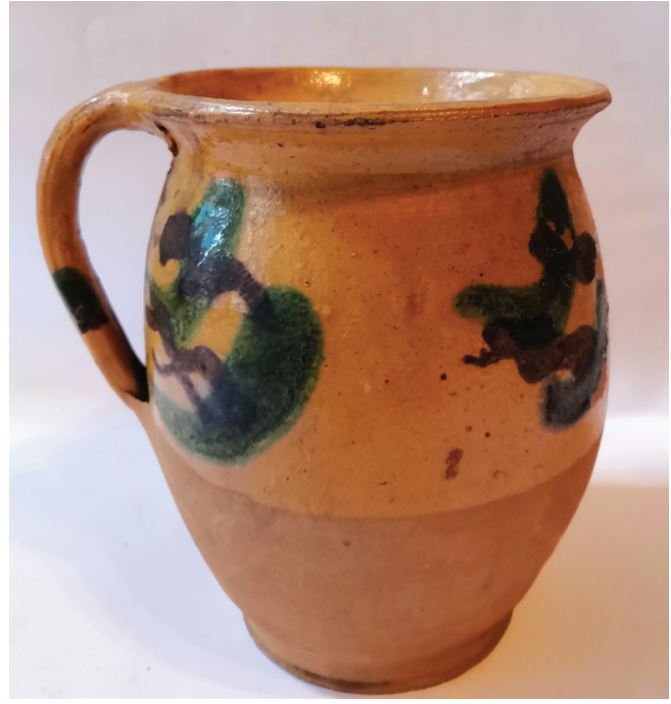

Іл. 2. Горщик. 1930-ті рр. Павлів. МЕХП. Фото Галини Івашків. віялоподібних композицій білого кольору (Антон Славінський, МЛЛ) тощо. Трапляються горщики 3 видовженим корпусом, на яких композиції з коротких брунатних кривульок і зелених зигзагів на корпусі вдало гармоніюють 3 жовтим тлом (Павлів, МЕХП; іл. 2). Майстри рідше робили орнаментальний наголос на плічках горщика, наприклад, поєднуючи мотиви „спіралей” і коротких скісних смуг білого ангобу (Ян Квятковський, ДЕМВ), білих „спіралей” чи „гірлянди” 3 плямами зеленої поливи ${ }^{28}$.

Цікавими є й особливості використання кераміки в календарних і родинних обрядах. Так, перед постом холмщаки добре мили горщики в річці, „щзоби не були тлусті” ${ }^{29}$. Коли дівчина йшла за невістку, то „ій у посаг родичі обов 'язково дарували горщики"зо .

3 горщиками, наповненими попелом, пов'язували свято „попелець”, яке відзначали у першу середу Великого посту: хлопці та дівчата переодягалися - там, де господарі добре приймали, то не сипали попелу, а де ні - в попелі були всі присутні та їхні помешкання ${ }^{31}$.

Серед виробів I. Славінського й прикрашені технікою гладження димлені горщики-двійнята (близнята), в яких десь до початку XX ст. носили їжу в поле (МЛЛ). Користувалися попитом і великі сільнички - посудини, що формою нагадують горщик з вивернутими назовні вінцями, проте вони різняться вухом, яке обома кінцями міститься на їхніх вінцях. Прикрашення однієї з них складено з ряду вертикальних гладжених „сосонок” на корпусі (І. Славінський, МЛЛ). Деякі такі вироби ззовні і всередині майстри вкривали темно-зеленою поливою (Павлів, МЕХП).

\footnotetext{
28 Збірка Тадея Карабовича (Люблін, Польща).

29 Записано 7.06.2019 р. у Влодаві від Кароліни Дем’янюк, 1939 р. н. і Катерини Веремчук, 1935 р. н., уродженок с. Долгоброди.

30 Записано 7.06.2019 р. у Влодаві від Кароліни Дем'янюк і Катерини Веремчук.

$31 \quad$ O. Kolberg, op. cit., s. 132.
} 
Дзбани 3 Павлова відзначалися виразною тектонічною структурою 3 виокремленням пійла, шийки та корпусу, а декор здебільшого поділявся на два горизонтальні орнаментальні поля 3 гладженими мотивами скісних хрестів i вертикальних смуг на шийці та скісних смуг, що чергуються 3 колами на корпусі ${ }^{32}$. Середину шийки дзбанка інколи прикрашали горизонтальним потовщенням, а далі донизу йшли вертикальні гладжені лінії та смуги з лискованих кіл, накладених одне на інше (МЛВП). Дзбани призначалися для води чи алкогольних напоїв (вина, горілки, пива ${ }^{33}$ ), а на Різдво до них наливали узвар (компот із місцевих сушених фруктів) (Іл. 3).

Із посуду 3 білим тлом виокремимо дзбанок кінця 1940-х pp., декор якого складено з кількох орнаментальних полів геометрично-рослинного характеру. Серед мотивів трикутники, закрути, багатопелюсткові розетки, звивисті гілочки та мотив, подібний до свастики (І. Славінський, МЛЛ). Ймовірно, цей дзбан, розпис якого наповнений багатьма символами, був призначений для перенесення та зберігання свяченої води ${ }^{34}$ (Іл. 4).

Дзбанки 3 тлом цеглястого кольору у виконанні І. Славінського мають поділ на чотири горизонтальні орнаментальні

\footnotetext{
32 R. Reinfuss, Garncarstwo ludowe..., op. cit., tab. 9.

33 Про дзбани з пивом на жалобній гостині (umerlynach) холмщаків писав О. Кольберг (див.: op. cit., s. 177).

34 Г. Івашків, Декор української... ор. cit., с. 182.
} 
поля (найбільше міститься на корпусі) та характеризуються варіативністю композиційних схем:

- короткі „сосонки” і скісні хрести;

- довгі скісні „сосонки” і крапчасті розетки;

- малі „сосонки” і великі перехресні розети тощо (МЛЛ).

Двоколірне (білий i брунатний) вирішення декору дзбанків із цеглястим тлом практикував Антон Славінський, застосовуючи при цьому мотиви вертикальних ліній, рядів крапок, крапчастих розеток та закрутів (МЛЛ). Фон його виробів інколи був темно-брунатним, на якому розпис білого кольору (кривульки, крапчасті розетки і „сосонки”) сприймався дуже виразно.

Поширеним було виготовлення димлених гладущиків (гладишок, глечиків, пол. „zliwok na mleko” ${ }^{35}$ ), у яких відстоювали молоко, а широкі горловини сприяли зручному збиранню сметани та миттю посудини. Ці вироби закритого типу здебільшого мали довгу шийку, одне вухо та видовжений корпус, рідше були без вух. Їхній декор складався з таких мотивів:

- ритовані горизонтальні лінії на шийці та вертикальні гладжені на корпусі (Влодава, МЕХП);

- гладжені вертикальні смуги на шийці, „віночок” зі скісних хрестів та овалів на корпусі (І. Славінський, Павлів, МЛЛ);

- гладжені вертикальні смуги на шийці, „віночок” зі скісних хрестів i ,сосонок” на корпусі (І. Славінський, МЛЛ);

- гладжені вертикальні смуги на шийці, кривульки на плічках і „віночок” з овалів на корпусі (І. Славінський, МЛЛ) тощо.

Глечики застосовували і в поховальній обрядовості. Коли людина помирала, біля ії голови ставили два глечики з зерном і свічками, що було символом життя та виражало віру в магічну силу зерна ${ }^{36}$.

Димлені гладущики-великани роботи І. Славінського, ймовірно, призначалися для молока у великому об'ємі або зберігання сипучих продуктів (МЛЛ). До них кріпилося одне масивне вухо майже під прямим кутом.

Наприкінці XIX - на початку XX ст. у побуті поширеними були й димлені баньки - посудини з короткою вузькою шийкою, одним вухом і кулястим корпусом. У них тримали олію або носили воду в поле. Ці предмети гончарі декорували групами скісних смуг і кривульок (Влодава, МЕХП) або „віночком” зі скісних хрестів та овалів (Павлів, МЛЛ) у техніці лискування. Поширеними були й баньки, вкриті цеглястою поливою (МВЛП) (Іл. 5).

\footnotetext{
35 O. Kolberg, op. cit., s. 84.

36 В. Борисенко, Обряди життєвого ичиклу людини, [в:] Холмщиина і Підлящшя. Історико-етнографічне дослідження, Київ 1997, с. 302.
} 
Для випікання пасок (бабок) напередодні Великодня мешканці Холмщини використовували досить високі глиняні посудини конусоподібної форми - бабники, які були переважно без вух, з рівними або карбованими боками та вивернутими назовні вінцями. Деякі з них у центрі корпусу з одного боку могли мати вухо, з іншого - утор (Павлів, МЛЛ) або два вуха обабіч (МЛВП) (Іл. 6).

Для топлення жиру мешканці послуговувалися й ринками-триніжками 3 довгою ручкою (пол. tygli) ${ }^{37}$. Функціональне призначення досить великих (10 x 44 х 26,5 см) ринок овальної форми 3 двома вухами могло бути пов'язане з запіканням м'яса у період календарних чи родинних свят. $\mathrm{y}$ таких ринках на Великдень носили й святити приготовлене м'ясо та інші страви. Певної святковості зовнішній поверхні виробу додавала лискована поверхня 3 мотивом „сітки” (МЛЛ). Зазначу, що на дні виробу є два округлі отвори для витікання жиру.

Для повсякденного вжитку поширеним було виготовлення предметів відкритого типу - димлених мисок, полумисків і тарілок без декору або

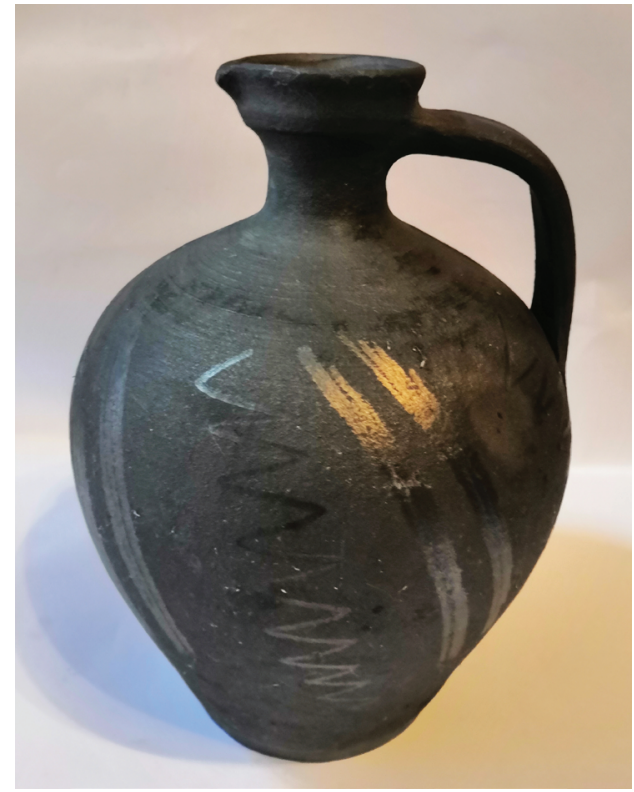

Іл. 5. Банька. 1930-ті рр. Влодава. МЕХП. Фото Галини Івашків.

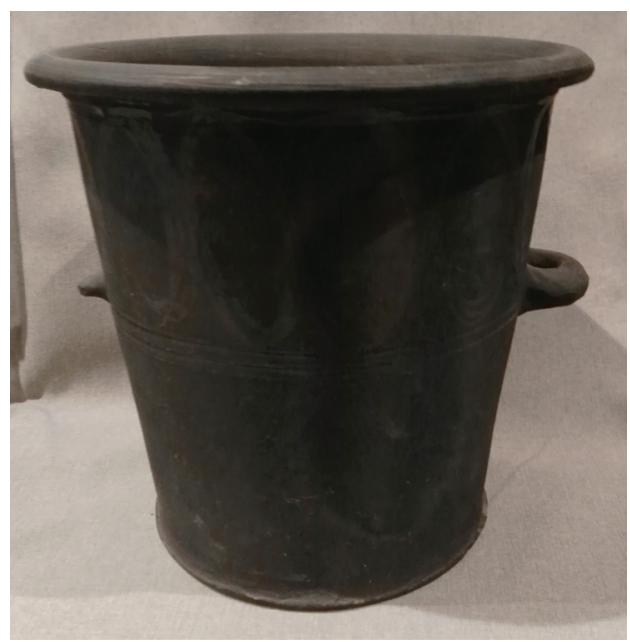

Іл. 6. Бабник. Поч. XX ст. Павлів. МІМЛ. Фото Галини Івашків. 3 гладженими мотивами „зірок” чи розеток на дні (Павлів, МЛЛ). Мотиви „зірок”, вихрових розеток та мазки зеленої поливи або мотив „зірки”,

37 O. Kolberg, op. cit., s. 84. 
„сосонок” і кривульки зеленої поливи - основні складові декору майолікових мисочок з жовтим тлом (Павлів, МЕХП). Траплялися й миски, прикрашені гачками зеленої поливи (Павлів, МЛВП) (Іл. 7).

Такі вироби подекуди виконували й обрядову функцію - під час хрестин,

коли вся родина повернулася з иеркви, то баба, що приймала роди, збирала гроші на глиняну миску⿰氵丶⿸⿴巳一丶 медом чи иукром ${ }^{39}$.

Згідно традиції, в окремих селах кума йшла до дитини і іiі матері 3 мискою пирогів або книшів у першу неділю по хрестинах чи в перше велике свято ${ }^{40}$.

Ннаприкінці весільної церемонії, при накладанні чіпця, розбивали тарілку („талірку”):

А відбувалося це так: музики грали „на чепечок” і тоді дружка танцювала з кожним гостем, який мав кинути гроші на хустку, що була в таліриі. У кінці дійства хустку зав 'язували, а талірку треба було розбити на якнайбільшу кількість малих частинок - аби було більще щастя ${ }^{41}$.

На Влодавщині у день поховання готували коливо (варену пшеницю 3 медом - кутю), яке викладали на миску ${ }^{42}$. Рідше трапляються тарілки (6 x 17, 3 см) з лискованим мотивом хреста в центрі (НМК). Ймовірно, у них до храму на поминальні служби й носили коливо. Окрім того, на Холмщині в день поминок у церкві ставили миску з пирогами, яблуками, сиром, ковбасами ${ }^{43}$. У деяких населених пунктах така наповнена миска „ночувала” в церкві. Коли щэось панові Богові не сподобалося, то могло впасти вночі на підлогу ${ }^{44}$.

Майже у кожному гончарному центрі України перед релігійними святами, особливо Різдвом, гончарі виробляли багато макітер, оскільки господині тоді намагалися купувати нові. Відомо, що в них терли мак до ритуальної страви - куті, а страву подавали на стіл саме в макітрах. У побуті макітра, одна з найпоширеніших типологічних груп кераміки, часто виконувала роль горщика і миски. Розміри макітри впливали на іï функ-

\footnotetext{
Записано 7.06.2019 р. у Влодаві від Кароліни Дем'янюк і Катерини Веремчук.

В. Борисенко, ор. cit., с. 282.

O. Kolberg, op. cit., s. 176.

Записано 7.06.2019 р. у Влодаві від Кароліни Дем'янюк і Катерини Веремчук.

В.Борисенко, ор. cit., с. 304.

Ibidem.

O. Kolberg, op. cit., s. 191.
} 
ціональне призначення - у великих (їх часто називали „опарники”) замішували тісто, у середніх - терли мак i ставили страви на стіл, малих - розтирали сир, часник або конопляне насіння. Мешканці Холмщини та Підляшшя макітри називали по-різному: дівниця, дивниця, макутра ${ }^{45}$, рідше - дуніцуа, дуйниияя (dónica, dójnycia) ${ }^{46}$, доніц̧а ${ }^{47}$ чи вертяга ${ }^{48}$.

На Різдво у вертязі вертіли мак $i$ подавали кутю, палюхи з маком, раиухи (з муки, на дріжджах і посипали иукром) та кисіль, а на весілля - м'ясо ${ }^{49}$ (Іл. 8).

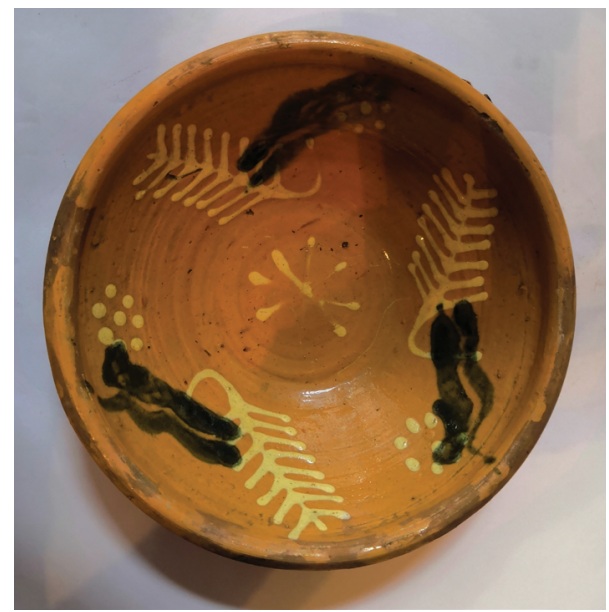

Іл. 7. Мисочка. 1930-ті рр. Павлів. МЕХП. Фото Галини Івашків.

Макітри гончарів Влодави i Павлова мали подібну форму - мале дно, від якого виходили високі розхилені боки 3 вивернутими вінцями. Ззовні їх декорували лощенням із використанням ліній, кривульок, овалів тощо ${ }^{50}$, інколи - без оздоблення

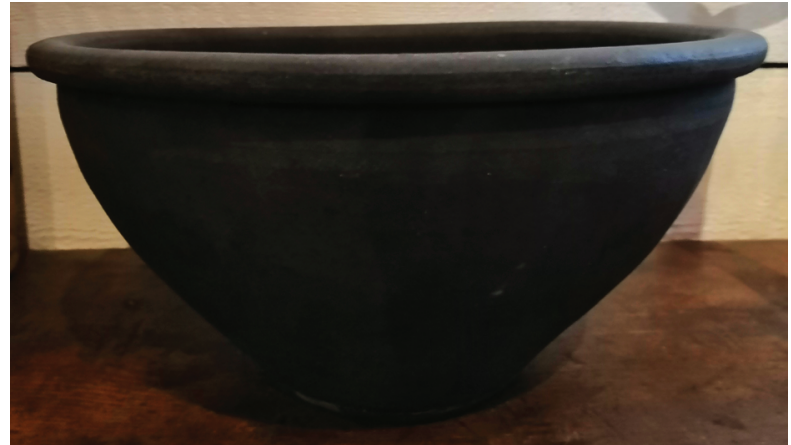

Іл. 8. Макітра. Поч. ХХ ст. Волдавський повіт. МЛВП. Фото Галини Івашків.

(МЛВП). Населення

Влодавського повіту користувалося переважно теракотовими макітрами (МГВУ), а мальовані макітри прикрашали досить скупо: деякі вироби до середини корпусу вкривали безколірною поливою.

\footnotetext{
45 В. Борисенко, Повсякденна їжа та ритуальні страви, [в:] Холмщиина і Підлямшя. Історико-етнографічне дослідження, Київ 1997, с. 216.

46 O. Kolberg, op. cit., s. 84.

47 Записано 8.06.2019 р. у Волі Угруській Влодавського повіту від заступника директора місцевої гімназії Іоланти Шахалай.

48 Записано 7.06.2019 р. у Влодаві від Кароліни Дем'янюк і Катерини Веремчук.

49 Записано 7.06.2019 р. у Влодаві від Кароліни Дем'янюк і Катерини Веремчук.

50 Збірка Тадея Карабовича.
} 
Предметами інтер'єру церков або помешкань були димлені флакони для живих і штучних квітів. Такі вази за формою поділялися на два види: 1) уподібнені до гладущиків без вух (Влодава, МЕХП, МЛЛ);

2) 3 виразною тектонікою - довгою шийкою, округлим корпусом і двома великими вухами (Влодава, МЕХП). Їх декорували ритуванням і лискуванням, а в предметах без оздоблення особливий наголос спрямовувався на форму. У багатьох гончарних осередках України вази для церков мали крайковані вінця.

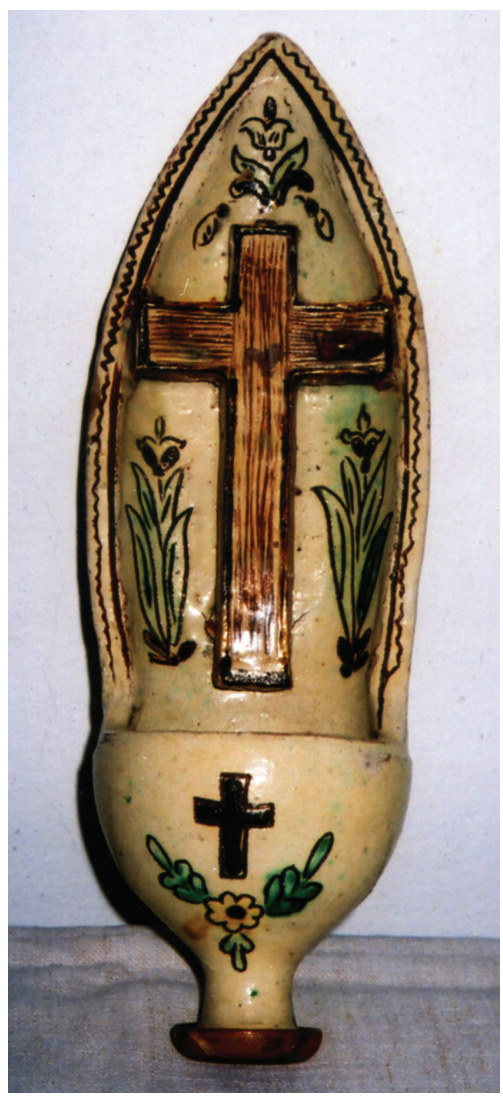

Іл. 9. І. Славінський. Кропильниця. 1948 р. Павлів. МІМЛ. Фото Галини Івашків.

До обрядових предметів належать кропильниці, автором яких у Павлові був I. Славінський. Одна 3 них, датована 1948 р., з резервуаром для свяченої води і трикутним верхом, розписана в „гуцульсько-покутському” стилі: 3 мотивами двох хрестів (один більший - рельєфний, другий менший - ритований) 3 видовженим нижнім кінцем, мотивами „вазонів” та гілок 3 розетками і пуп'янками зеленого, брунатного і жовтого кольорів на білому тлі (МЛЛ). Форма кропильниці інколи нагадувала модель каплички (МЛЛ). Інші кропильниці І. Славінського були 3 подібним низом, але округлим верхом, проте вирізнялися особливим декоративним наповненням - на цеглястому фоні рельєфний хрест, ритовані півдуги і зелені мазки поливи вгорі та по боках рельєфного хреста або довкола середохрестя хреста ритовані „сонячні" промені, а обабіч хреста мотиви „вазонів” (МЛЛ) (Іл. 9).

Інтерес викликають i димлені свічники 3 округлими основами, двома-трьома потовщеннями i великим вухом (від вінець до краю основи), а також свічники-трійці, виготовлені на зразок прикарпатських, декорованих гладженням і ритуванням (I. Славінський, МЛЛ).

Майстри з Павлова виробляли димлені, вкриті лише поливою, та мальовані скарбонки, що призначалися для накопичування монет. Скарбонки здебільшого мали форму кулі, рідше - вежі або з пластичним еле- 
ментом. Димлені - переважно без декору або з хаотичними лискованими лініями, а майолікові оздоблені геометричним орнаментом з мотивами ліній і кривульок (І. Славінський), пластичних композицій на завершенні (К. Цехомська). І. Славінський був автором полив'яних пластичних керамічних виробів, зокрема фігурки коня 3 довгою шиєю та циліндричним корпусом (МЛЛ).

Посуд та інші глиняні вироби гончарі з Холмщини розвозили по селах, коли там був відпуст, або на ярмарки, які відбувалися в містечках ${ }^{51}$. О. Кольберг зафіксував цікавий спосіб „продовження життя” горщиків, які практикували холмщаки - дірки на посудинах ніби „зашивали”52.

Отож, у статті розглянуто діяльність двох гончарних осередків Холмщини - Влодави і Павлова. Їхня історія сягає XVI ст., а найбільшу кількість майстрів зафіксовано у першій половині XX століття. На численних прикладах вказано основні види кераміки - димлену і мальовану, визначено типологічні групи та особливості декору виробів, названо музеї та приватні збірки, де вони зберігаються.

Із мальованої кераміки Павлова виокремлено предмети з білим та цеглястим тлом. Однією з найбільших типологічних груп кераміки вважається посуд, який мешканці використовували для повсякдення, а також для обрядів календарного і родинного циклів. Аналогічні глиняні вироби виготовляли і в інших історико-етнографічних регіонах України.

\section{BIBLIOGRAFIA}

Borisenko Valentina. 1997. Obrâdi žittêvogo ciklu lûdini. V: Holmŝina ì Pìlâššâ. İstorikoetnografične doslidžennâ. Kiïv: Rodovìd: 280-309. [Борисенко Валентина. 1997. Обряди життєвого ичиклу людини. В: Холмщчина і Підляшщя. Історико-етнографічне дослідження. Київ: Родовід: 280-309].

Borisenko Valentina. 1997. Povsâkdenna iža ta ritual'nì stravi. V: Holmŝina i Pìlâššâ. İstoriko-etnografične doslidžennâ. Kiïv: Rodovìd: 215-222. [Борисенко Валентина. 1997. Повсякденна їжа та ритуальні страви. В: Холмщчина і Підляшшя. Iсторико-етнографічне дослідження. Київ: Родовід: 215-222].

Ìvaškìv Galina. 2007. Dekor ukraïns'koï narodnoï keramiki XVI-peršoï polovini XX stolit'. L'vìv: İnstitut Narodoznavstva NAN Ukraïni. [Івашків Галина. 2007. Декор української народної кераміки XVI - першої половини XX століть. Львів: Інститут народознавства НАН України].

Kara-Vasil'êva Tetâna. 1997. Remesla ì narodne mistectvo. Gončarstvo. V: Holmŝina i Pidlâššâ. İstoriko-etnografične doslidžennâ. Kiïv: Rodovìd: 223-231. [Кара-Васильєва Тетяна. 1997. Ремесла і народне мистецтво. Гончарство. В: Холмщина і Підляшия. Історико-етнографічне дослідження. Київ: Родовід: 223-231].

51 O. Kolberg, op. cit., s. 84.

52 Ibidem. 
Kolberg Oskar. 1890. Chetmskie (obraz etnograficzny). Kraków: W drukarni uniwersytetu Jagiellońskiego.

Laŝuk Urìj. 1992. Narodne mistectvo Ukraïns'kogo Polissâ. L'vìv: Kamenâr. [Лащук Юрій. 1992. Народне мистецтво Украӥнського Полісся. Львів: Каменяр].

Michalski Stefan. 1939. Włodawa. Monografia statystyczno-gospodarcza. Lublin: Towarzystwo Naukowe Katolickiego Uniwersytetu Lubelskiego.

Reinfuss Roman. 1955. Garncarstwo ludowe. Warszawa: Sztuka.

Reinfuss Roman. 1961. Na marginesie badań sztuki ludowej Białostocczyzny. W: „Polska Sztuka Ludowa" nr 3: 131-136.

Reinfuss Roman. 1962. Sztuka ludowa na pograniczu Lubelszczyzny i Podlasia. W: Studia i Materiały Lubelskie. Etnografia. Lublin: Muzeum w Lublinie: 136-138.

Słownik geograficzny Królestwa Polskiego i innych krajów słowiańskich. 1886. Warszawa t. 7: 905 .

Słownik geograficzny Królestwa Polskiego i innych krajów słowiańskich. 1893. Warszawa t. 13: 712 .

Włodawa - The Card of Cultural Heritage. W: http: // shtettrotes.eu/en/włodawa-the-cardof-national-heritage [Dostęp 29.05.2020].

\section{THE EARTHENWARE OF WŁODAWA AND PAWŁOW: HISTORY, TYPOLOGY AND ARTISTIC SPECIFICITY}

Summary. The given paper highlights the history of pottery in Włodawa and Pawłów until mid- $20^{\text {th }} \mathrm{c}$. Considerable deposits of clay that was especially rich in iron oxide allowed the local potters to manufacture mostly smoked earthenware items. Painted earthenware appeared in Pawłów thanks to the potters from Pre-Carpathians, in particular the ones from Kuty in Ivano-Frankivsk region. The author of the given article defines major typological groups of the earthenware (crockery, items for home and church interiors, namely vases, moneyboxes and toys) and provides potters' names. The paper also explores artistic specificity, particularly fundamental decoration techniques of the smoked (e.g. smoothening and scratching) as well as painted earthenware (e.g. painting the works with multi-coloured engobes and glazing). A number of earthenware items have been used in rituals of the calendar and family cycle.

Key words: pottery, Włodawa, Pawłów, types of earthenware, décor

\section{CERAMIKA WŁODAWY I PAWŁOWA: HISTORIA, TYPOLOGIA, CECHY ARTYSTYCZNE}

Streszczenie. W artykule omówiono historię rozwoju garncarstwa we Włodawie i Pawłowie do połowy XX wieku. Obfite pokłady gliny wyjątkowo bogatej w tlenki żelaza umożliwiały lokalnym rzemieślnikom przede wszystkim produkcję wyrobów ceramicznych techniką wypalania bez dostępu powietrza. Cech garncarski we Włodawie uzyskał w XVI w. znaczne przywileje pozwalające na wytwarzanie różnego rodzaju naczyń. Ceramika malowana trafiła do Pawłowa dzięki garncarzom z Przykarpacia, głównie z Kut (byłe województwo stanisławowskie; obecnie obwód iwano-frankiwski). Scharakteryzowano typologię ceramiki (naczynia, przedmioty wyposażenia wnętrz cerkwi i mieszkań - wazy, 
skarbonki, a także zabawki), wymieniono nazwiska rzemieślników. Przeanalizowano walory artystyczne wyrobów garncarskich, w szczególności główne techniki zdobienia ceramiki siwej (gładzenie, rytowanie) i ceramiki malowanej (zdobienie kolorowymi angobami i glazurowanie). Wskazano na zastosowanie pewnych wyrobów ceramicznych w obrzędach dorocznych i rodzinnych.

Słowa klucze: garncarstwo, Włodawa, Pawłów, typy ceramiki, zdobienie 
